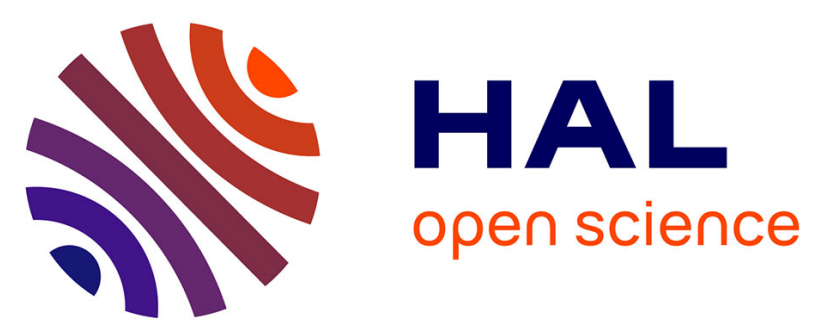

\title{
Evaluation of the roles of metals and humic fractions in the podzolization of soils from the Amazon region using two analytical spectroscopy techniques
}

Amanda Tadini, Gustavo Nicolodelli, Bruno S Marangoni, Stéphane Mounier, Celia Montes, Débora M.B.P. Milori

\section{To cite this version:}

Amanda Tadini, Gustavo Nicolodelli, Bruno S Marangoni, Stéphane Mounier, Celia Montes, et al.. Evaluation of the roles of metals and humic fractions in the podzolization of soils from the Amazon region using two analytical spectroscopy techniques. Microchemical Journal, 2019, 144, pp.454-460. 10.1016/j.microc.2018.10.009 . hal-01889129

\section{HAL Id: hal-01889129 \\ https://hal.science/hal-01889129}

Submitted on 5 Oct 2018

HAL is a multi-disciplinary open access archive for the deposit and dissemination of scientific research documents, whether they are published or not. The documents may come from teaching and research institutions in France or abroad, or from public or private research centers.
L'archive ouverte pluridisciplinaire HAL, est destinée au dépôt et à la diffusion de documents scientifiques de niveau recherche, publiés ou non, émanant des établissements d'enseignement et de recherche français ou étrangers, des laboratoires publics ou privés. 


\title{
Evaluation of the roles of metals and humic fractions in the podzolization of soils from the Amazon region using two analytical spectroscopy techniques
}

\author{
Amanda M. Tadini ${ }^{(a, b, d) *}$, Gustavo Nicolodelli(a,c), Bruno S. Marangoni ${ }^{(c)}$, Stephane \\ Mounier $^{(\mathrm{d})}$, Célia R. Montes ${ }^{(\mathrm{e})}$, Débora M. B. P. Milori( ${ }^{(a)}$ \\ (a) Embrapa Instrumentation, São Carlos, SP, Brazil \\ (b) Institute of Chemistry of São Carlos, University of São Paulo, São Carlos, SP, Brazil \\ (c) Institute of Physics, Federal University of Mato Grosso do Sul, P.O. Box 549, \\ 79070-900 Campo Grande, MS, Brazil \\ (d) Laboratoire PROTEE, EA3819, Université de Toulon, CS 60584, 83041 Toulon \\ CEDEX 9, France \\ (e) Centro de Energia Nuclear na Agricultura e Núcleo de Pesquisa em Geoquímica e \\ Geofísica da Litosfera, Universidade de São Paulo, Piracicaba, SP, Brazil \\ *Corresponding author. E-mail: amandatadini@hotmail.com
}




\begin{abstract}
Soil organic matter (SOM) plays an important role in environmental sustainability, since it is involved in carbon and nutrient cycling. Consequently, it is a key factor to consider in studies concerning global climate change and agronomy. Among the main components of SOM are humic substances (HS), which are divided, according to their solubility, into humic acid (HA), fulvic acid (FA), and humin (HU) fractions. Study of the chemical properties of this organic matter is important for understanding the biogeochemical processes occurring in the soil. The aim of this work was to determine the metals iron $(\mathrm{Fe})$ and aluminum $(\mathrm{Al})$, using flame atomic absorption spectrometry (FAAS) and laser-induced breakdown spectroscopy (LIBS), in order to elucidate the role of organic matter in the transport of these metals in Amazonian soils. The results showed that FA was important for Al, while the HA fraction was more selective towards Fe. The translocations of these metals to deeper profiles in two different soils involved either young and less humified organic matter, or older organic matter with a low degree of humification. Therefore, these two humic fractions were involved in the process of soil podzolization, with FA having a predominant role in the transport of $\mathrm{Al}$, while $\mathrm{HA}$ was mainly responsible for the transport of Fe.
\end{abstract}

Keywords: LIBS, FAAS, Organic matter, Amazon. 


\section{Introduction}

The Amazon forest provides important services to humanity and the environment, including high biodiversity, climate regulation, carbon sequestration, and regulation of water and nutrient cycles. Soils play crucial roles in most of the processes that occur on the planet, due to their participation in the main biogeochemical cycles [1]. These involve pedogenetic processes transforming rocks and sediments, whose characteristics are influenced by combinations of soil formation factors such as the source material, climate, microorganisms, and time [2].

In the Amazon, Spodosols develop over time from clay soil or sedimentary formations. Organometallic iron (Fe) and aluminum (Al) oxides present in horizons A and $\mathrm{E}$ are transported to deeper soil layers, where they accumulate and give rise to horizons rich in organic matter and organometallic species [3]. Hence, organic matter in these soils plays a key role in environmental sustainability, since it is related to carbon and nutrient cycling, and is a crucial factor to consider in studies in the fields of global climate change and agronomy. Humic substances (HS) are among the main components of SOM and can be classified, according to their solubility, into humic acid (HA), fulvic acid (FA), and humin (HU) fractions [4].

Determination of the chemical properties of the organic matter, as well as its interaction with metallic species, is essential for understanding the main processes that occur in the soil. The techniques that have been described for this purpose include flame atomic absorption spectrometry (FAAS) and, more recently, laser-induced breakdown spectroscopy (LIBS). The latter is an attractive technique due to its high sensitivity and precision, as well as the requirement for only minimal sample preparation, making it attractive for use in applications that comply with the concepts of Green Chemistry [5]. This technique is a type of atomic emission spectrometry that uses the generation of plasma by means of high power pulses, resulting in ablation of a small portion of the sample. This material dissociates into ions and excited atoms, emitting a continuum of radiation that enables the measurement of atomic/ionic emission lines and identification of the main elements present in the sample [6].

The main advantages of LIBS are the potential for simultaneous multi-element soil analysis with minimal sample preparation, high processing speed, and low cost of analysis, compared to traditional methods. The LIBS technique has been evaluated as an alternative method for the quantification of contaminants, macro/micronutrients, and carbon (C) in soils [7-9]. It has been used in investigations of texture, $\mathrm{pH}$, and macro- 
and micronutrients in fertilizers and soil organominerals [10-12]. However, although LIBS has been used for soil analysis, it has not previously been employed to investigate the chemical fractions present in the soil.

The aim of this study was to use the FAAS and LIBS techniques to quantify the metals Fe and Al in Amazonian Spodosols. The metals were quantified in whole soil samples and in the different humic fractions (HA, FA, and HU), in order to understand the role of the SOM in the transport of these metals during the podzolization process.

\section{Materials and Methods}

\subsection{Study area}

The soil samples (two Spodosols, denoted P1 and P4) were obtained from a site located in the north of the municipality of Barcelos, near the Demeni River $\left(0^{\circ} 15^{\prime} 18^{\prime \prime} \mathrm{N} ; 62^{\circ} 46^{\prime} 36^{\prime \prime} \mathrm{W}\right)$ in the middle watershed of the Negro River region in the Amazon plains of Brazil. The regional geology is characterized by sediments of the Içá formation. Sample P1 was from a permanently waterlogged podzol covered by herbaceous meadow of scrubs and grass, locally known as "campina". Sample P4 was from a well-drained podzol under rainforest vegetation, with no influence of groundwater. Further details of the study area can be found in Tadini et al. [13].

\subsection{Preparation of the samples for analysis}

The procedures adopted for sampling, preservation, and preparation of the soils followed the recommendations of official methods [14-16]. Extraction and purification of the humic acid (HA), fulvic acid (FA), and humin (HU) fractions followed the procedures proposed by the International Humic Substances Society (IHSS), as used by Rice and MacCarthy [17], and Swift [18].

\subsection{Flame atomic absorption spectrometry (FAAS)}

Sample decomposition was performed using $100 \mathrm{mg}$ portions of the soils and the humic fractions (HA, FA, and HU), following the recommendations of the United States Environmental Protection Agency (Method 3052) [19]. Quantification of Fe and Al was performed using a PerkinElmer PinAAcle 900T flame atomic absorption spectrometer. Calibration curves were constructed using metal standard solutions and a blank (water) prepared in $1.0 \mathrm{~mol}^{-1} \mathrm{HCl}$ (comparable to the sample preparation). 


\subsection{Laser-induced breakdown spectroscopy (LIBS)}

The LIBS system employed a Nd:YAG laser operating at $532 \mathrm{~nm}$ in the visible (VIS) region. The VIS pulse had a maximum energy of $180 \mathrm{~mJ}$, a width of $4 \mathrm{~ns}$, and was generated by a Quantel Brilliant Q-Switched Nd:YAG laser coupled to a second harmonic generator module. . An ARYELLE 400-Butterfly system was used to detect and select the wavelengths. The spectrometer was operated in the spectral range 175$330 \mathrm{~nm}$, with resolution of 13-24 pm, and was equipped with an intensified chargecoupled device $($ ICCD) camera $(1024 \times 1024$ pixels $)$. The beam from the lasers was directed and focused on the sample by means of dichroic mirrors at appropriate wavelength. Two lenses were placed between the sample and the tip of the fiber, for efficient collection of the emitted plasma. The sample support was placed in a microcontrolled $\mathrm{x}-\mathrm{y}$ stage to enable easy and fast scanning by the laser beam impinging on it. An eight-channel pulse generator (Model 9618, Quantum Composers) was used to synchronize the delay time between pulse and the detection acquisition during the experiments.

Acquisition of the LIBS spectra was performed using a $532 \mathrm{~nm}$ visible laser beam with energy of $30 \mathrm{~mJ}$ and accumulation of 5 laser shots. The beam was focused and aligned to hit the sample in overlapping laser shots mode.. The gate width was set at $1.5 \mu \mathrm{s}$ and the gate time at $1.0 \mu \mathrm{s}$. Each whole soil and humic fraction sample was submitted to 30 measurements performed in different positions.

The outlier spectra were excluded using a technique called Spectral Angle Mapper (SAM) [20], involving calculation of a normalized scalar product between the individual spectrum and the average spectrum, returning a value between -1 and 1 . The closer the value is to 1 , the greater the similarity between the spectra. The imposition of a limit below 1 enables the exclusion of spectra that differ from the average. The use of this procedure resulted in elimination of only around $2 \%$ of the spectra, indicative of good stability of the experimental system. Finally, an average spectrum was calculated for each sample.

\subsection{Transitions identification}

Identification of the Fe and $\mathrm{Al}$ transitions was performed using pixel correlation [11] and the NIST database [21]. Briefly, calculation was made of the linear Pearson correlation between the intensity of a specific pixel and the variation of the concentration. This process was repeated for all pixels in the spectrum. The reference 
elemental concentration value was measured by FAAS. In this way, the pixels with higher correlation values were more likely to be representative of a transition line. This analysis assisted in eliminating saturated transitions and those with interference. As a result, three transition lines were selected for each metal: Al I $(237.20 \mathrm{~nm})$, Al II (265.25 nm), Al (281.62 nm), Fe I (248.33 nm), Fe II (273.95 nm), and Fe (302.05 and $302.06 \mathrm{~nm}$ ). The last Fe transition is a superposition of two Fe lines, so the integrated area of the entire region was used as a single intensity value.

\subsection{Multivariate calibration}

The LIBS intensity was linearly correlated with the Al and Fe concentrations of the samples, resulting in a calibration curve. The LIBS intensity was obtained by means of a multivariate calculation involving the areas for each transition and the area for the background, as shown in Equation 1:

$$
I=\alpha_{1} * A_{1}+\alpha_{2} * A_{2}+\alpha_{3} * A_{3}-\beta * C
$$

where $A_{\mathrm{i}}$ is the area of each atomic transition, $C$ is the background area, and $\alpha_{\mathrm{i}}$ and $\beta$ are positive parameters fitted to the best linear correlation. The $A_{\mathrm{i}}$ values were calculated by summing the intensities of pixels inside a transition. The value of $C$ was obtained as the sum of the intensities in a region with no apparent transitions.

\section{Results and Discussion}

Table 1 shows the values for carbon, $\mathrm{Fe}$, and $\mathrm{Al}$ in the whole soil samples and in the humic fractions extracted from the Amazonian Spodosols, obtained using FAAS. 
Table 1. Concentrations of carbon (\%) and the metals $\mathrm{Fe}$ and $\mathrm{Al}(\mathrm{g} / \mathrm{kg})$ in the whole soil samples and in the humic fractions (HA, FA, and HU) extracted from the Amazonian Spodosols.

\begin{tabular}{|c|c|c|c|c|c|c|c|c|c|c|c|}
\hline \multirow{2}{*}{ Metals } & \multicolumn{3}{|c|}{ Samples } & \multicolumn{4}{|c|}{ Carbon (\%) } & \multicolumn{4}{|c|}{ Concentration of metals $(\mathrm{g} / \mathrm{kg})$} \\
\hline & Area & Horizon & Depth (cm) & Soils & HA & FA & HU & Soils & HA & FA & HU \\
\hline \multirow{12}{*}{$\mathbf{F e}$} & \multirow{5}{*}{$\mathrm{P} 1$} & $\mathrm{~A}$ & $0-15$ & $22.5 \pm 0.9$ & $45 \pm 3$ & $18.2 \pm 0.5$ & $52.03 \pm 0.08$ & $1.20 \pm 0.01$ & $0.4 \pm 0.2$ & $0.07 \pm 0.01$ & $0.3 \pm 0.1$ \\
\hline & & A-E & $15-30$ & $1.01 \pm 0.09$ & $51 \pm 1$ & $26.9 \pm 0.2$ & $24.38 \pm 0.01$ & $0.95 \pm 0.01$ & $0.3 \pm 0.1$ & $*$ & $0.2 \pm 0.1$ \\
\hline & & $\mathrm{Bh}$ & $40-50$ & $2.1 \pm 0.2$ & $56.2 \pm 0.2$ & $36.8 \pm 0.8$ & $36.67 \pm 0.03$ & $0.77 \pm 0.01$ & $0.3 \pm 0.1$ & $0.12 \pm 0.01$ & $0.2 \pm 0.1$ \\
\hline & & $\mathrm{Bh}-\mathrm{C}$ & 240 & $3.2 \pm 0.2$ & $46 \pm 2$ & $47.9 \pm 0.1$ & $*$ & $6.44 \pm 0.01$ & $0.6 \pm 0.2$ & * & $0.4 \pm 0.1$ \\
\hline & & $\mathrm{C}$ & 350 & $1.2 \pm 0.2$ & $51 \pm 3$ & $38.7 \pm 0.9$ & $5.17 \pm 0.00$ & $2.13 \pm 0.01$ & $0.2 \pm 0.1$ & $0.07 \pm 0.01$ & $1.0 \pm 0.2$ \\
\hline & \multirow{7}{*}{ P4 } & A & $0-20$ & $3.9 \pm 0.2$ & $45.2 \pm 0.3$ & $34 \pm 3$ & $41.43 \pm 0.07$ & $2.29 \pm 0.01$ & $1.8 \pm 0.5$ & $0.2 \pm 0.1$ & $0.2 \pm 0.1$ \\
\hline & & A & $20-30$ & $3.5 \pm 0.2$ & $49.4 \pm 0.01$ & $21.6 \pm 0.2$ & $*$ & $2.28 \pm 0.01$ & $1.9 \pm 0.4$ & $*$ & $0.2 \pm 0.1$ \\
\hline & & A & $30-40$ & $0.89 \pm 0.01$ & $50 \pm 2$ & $10.8 \pm 0.1$ & $5.76 \pm 0.02$ & $2.60 \pm 0.01$ & $2.3 \pm 0.3$ & * & $0.3 \pm 0.1$ \\
\hline & & $\mathrm{Bh}$ & $110-120$ & $0.42 \pm 0.02$ & $50.0 \pm 0.1$ & $39.8 \pm 0.6$ & $*$ & $1.81 \pm 0.01$ & $1.1 \pm 0.2$ & $*$ & $0.4 \pm 0.1$ \\
\hline & & $\mathrm{Bh}$ & $170-180$ & $0.38 \pm 0.01$ & $52 \pm 6$ & $3.1 \pm 0.0$ & $5.33 \pm 0.02$ & $1.72 \pm 0.01$ & $1.4 \pm 0.2$ & $*$ & $0.3 \pm 0.1$ \\
\hline & & $\mathrm{Bh}$ & $370-380$ & $0.48 \pm 0.01$ & $52.8 \pm 0.3$ & $32.8 \pm 0.2$ & $2.26 \pm 0.01$ & $2.49 \pm 0.01$ & $1.2 \pm 0.6$ & * & $0.4 \pm 0.1$ \\
\hline & & $\mathrm{Bh}$ & $380-390$ & $0.78 \pm 0.01$ & $54.5 \pm 0.5$ & $34.5 \pm 0.3$ & $*$ & $1.66 \pm 0.01$ & $1.3 \pm 0.2$ & $*$ & $0.3 \pm 0.1$ \\
\hline \multirow{12}{*}{ Al } & \multirow{5}{*}{$\mathrm{P} 1$} & $\mathrm{~A}$ & $0-15$ & $22.5 \pm 0.9$ & $45 \pm 3$ & $18.2 \pm 0.5$ & $52.03 \pm 0.08$ & $43 \pm 1$ & $*$ & $16.8 \pm 0.2$ & $*$ \\
\hline & & A-E & $15-30$ & $1.01 \pm 0.09$ & $51 \pm 1$ & $26.9 \pm 0.2$ & $24.38 \pm 0.01$ & $39 \pm 1$ & $*$ & $13.8 \pm 0.5$ & $*$ \\
\hline & & $\mathrm{Bh}$ & $40-50$ & $2.1 \pm 0.2$ & $56.2 \pm 0.2$ & $36.8 \pm 0.8$ & $36.67 \pm 0.03$ & $57 \pm 1$ & $*$ & $8.8 \pm 0.3$ & $*$ \\
\hline & & $\mathrm{Bh}-\mathrm{C}$ & 240 & $3.2 \pm 0.2$ & $46 \pm 2$ & $47.9 \pm 0.1$ & $*$ & $92 \pm 1$ & $*$ & $*$ & * \\
\hline & & $\mathrm{C}$ & 350 & $1.2 \pm 0.2$ & $51 \pm 3$ & $38.7 \pm 0.9$ & $5.17 \pm 0.00$ & $52 \pm 1$ & $*$ & $20.0 \pm 0.1$ & $5.0 \pm 0.1$ \\
\hline & \multirow{7}{*}{$\mathrm{P} 4$} & A & $0-20$ & $3.9 \pm 0.2$ & $45.2 \pm 0.3$ & $34 \pm 3$ & $41.43 \pm 0.07$ & $48 \pm 1$ & $6.4 \pm 0.4$ & $9.5 \pm 0.1$ & $*$ \\
\hline & & A & $20-30$ & $3.5 \pm 0.2$ & $49.4 \pm 0.01$ & $21.6 \pm 0.2$ & $*$ & $47 \pm 1$ & $*$ & $27.2 \pm 0.2$ & $*$ \\
\hline & & A & $30-40$ & $0.89 \pm 0.01$ & $50 \pm 2$ & $10.8 \pm 0.1$ & $5.76 \pm 0.02$ & $46 \pm 1$ & $*$ & $17.5 \pm 0.1$ & $*$ \\
\hline & & $\mathrm{Bh}$ & $110-120$ & $0.42 \pm 0.02$ & $50.0 \pm 0.1$ & $39.8 \pm 0.6$ & $*$ & $39 \pm 1$ & $*$ & $13.7 \pm 0.4$ & $*$ \\
\hline & & $\mathrm{Bh}$ & $170-180$ & $0.38 \pm 0.01$ & $52 \pm 6$ & $3.1 \pm 0.0$ & $5.33 \pm 0.02$ & $49 \pm 1$ & $*$ & $16.5 \pm 0.3$ & $*$ \\
\hline & & $\mathrm{Bh}$ & $370-380$ & $0.48 \pm 0.01$ & $52.8 \pm 0.3$ & $32.8 \pm 0.2$ & $2.26 \pm 0.01$ & $41 \pm 1$ & $*$ & $20.5 \pm 0.2$ & $*$ \\
\hline & & $\mathrm{Bh}$ & $380-390$ & $0.78 \pm 0.01$ & $54.5 \pm 0.5$ & $34.5 \pm 0.3$ & $*$ & $51 \pm 1$ & $*$ & $21 \pm 1$ & $*$ \\
\hline
\end{tabular}

P1: hydromorphic spodosol; P4: well drained spodosol; * below the detection limit of the calibration curve (\% $=0.04 ; \mathrm{Fe}: 0.10 \mathrm{mg} / \mathrm{kg}$ and $\mathrm{Al}: 2.5 \mathrm{mg} / \mathrm{kg}$ ). 
The Al concentration profile showed an increase with greater depth in the horizons of soils P1 and P4 (Table 1). In the case of Fe, the highest values were found for the subsurface horizons (A and A-E) and the deep Bh horizons: Bh-C 240 (P1) and Bh 370-380 (P4). A possible explanation for this behavior was that in the case of the hydromorphic Spodosol (P1), there was mobilization of suspended organometallic complexes and metal oxides, controlled by the oscillating groundwater level. In flooded soils, anaerobic environments are created, with the organic matter acting as an electron receptor and enabling reduction of the macro- and micronutrients present $[23,24]$. Hence, the results suggested that there was greater mobilization of the organometallic complexes and the reduced iron in soil P1, compared to the well-drained Spodosol (P4), with the precipitation of $\mathrm{Fe}$ and decreasing mobilization of the organometallic complexes along the profile. Consequently, there was the accumulation of $\mathrm{Fe}$ in horizons with greater amounts of organic matter, resulting in spodic Bh horizons in this system.

The results obtained in this study were in agreement with the findings of Ishida [25] and Santos [22] for a Latosol-Spodosol system in the Amazon region. It was reported that there was accumulation of $\mathrm{Al}$ and $\mathrm{Fe}$ in the $\mathrm{Bh}$ horizons, with the highest value obtained for Al. This accumulation was suggested to be due to translocation of the metals, especially $\mathrm{Al}$, to the spodic $\mathrm{Bh}$ horizons in the form of organic complexes.

In previous work by Tadini et al. [13], involving the dating of these Amazonian Spodosols and determination of the humification indices, it was observed that soil P1 presented an accumulation of young organic material with a low degree of humification, which was displaced with depth, due to physical and chemical processes. The highest values for humification of the whole soil and for the humic acid fraction were obtained for the Bh-C horizon, at $240 \mathrm{~cm}$. The data obtained in the present study (Table 1) showed that this horizon presented the highest concentrations of $\mathrm{Fe}$ and $\mathrm{Al}$ in the whole soil and the humic fractions (HA, FA, and HU).

The well-drained Spodosol (soil P4) showed the contribution of old and poorly humified organic matter in horizons Bh 170-180 and Bh 370-380. Therefore, the results indicated that the transfer of iron and aluminum to deeper profiles of soil P1 involved the participation of young and less humified organic matter. Transfer of the metals in soil P4 involved older organic matter with a low degree of humification, which could be attributed to the presence of more recalcitrant compounds derived from lignin [13].

These results indicated that the three humic fractions were involved in the 
process of podzolization of the Amazonian Spodosols. The FA fraction played a predominant role in the transport of $\mathrm{Al}(8.8$ to $27.2 \mathrm{~g} / \mathrm{kg})$, since this fraction had the highest amount of this metal in its structure, while the HA fraction was responsible for the transport of Fe (0.2 to $2.3 \mathrm{~g} / \mathrm{kg})$.

The LIBS technique was also used for analysis of the whole soil samples and the humic fractions extracted from the Amazonian Spodosols. Figure 1 shows typical LIBS spectra obtained for horizon A of the hydromorphic Spodosol (P1).

Figure 1. Typical LIBS spectra for the hydromorphic spodosol (P1 A 0-15 cm): (a) whole soil, (b) humic acids, (c) fulvic acids, and (d) humin.
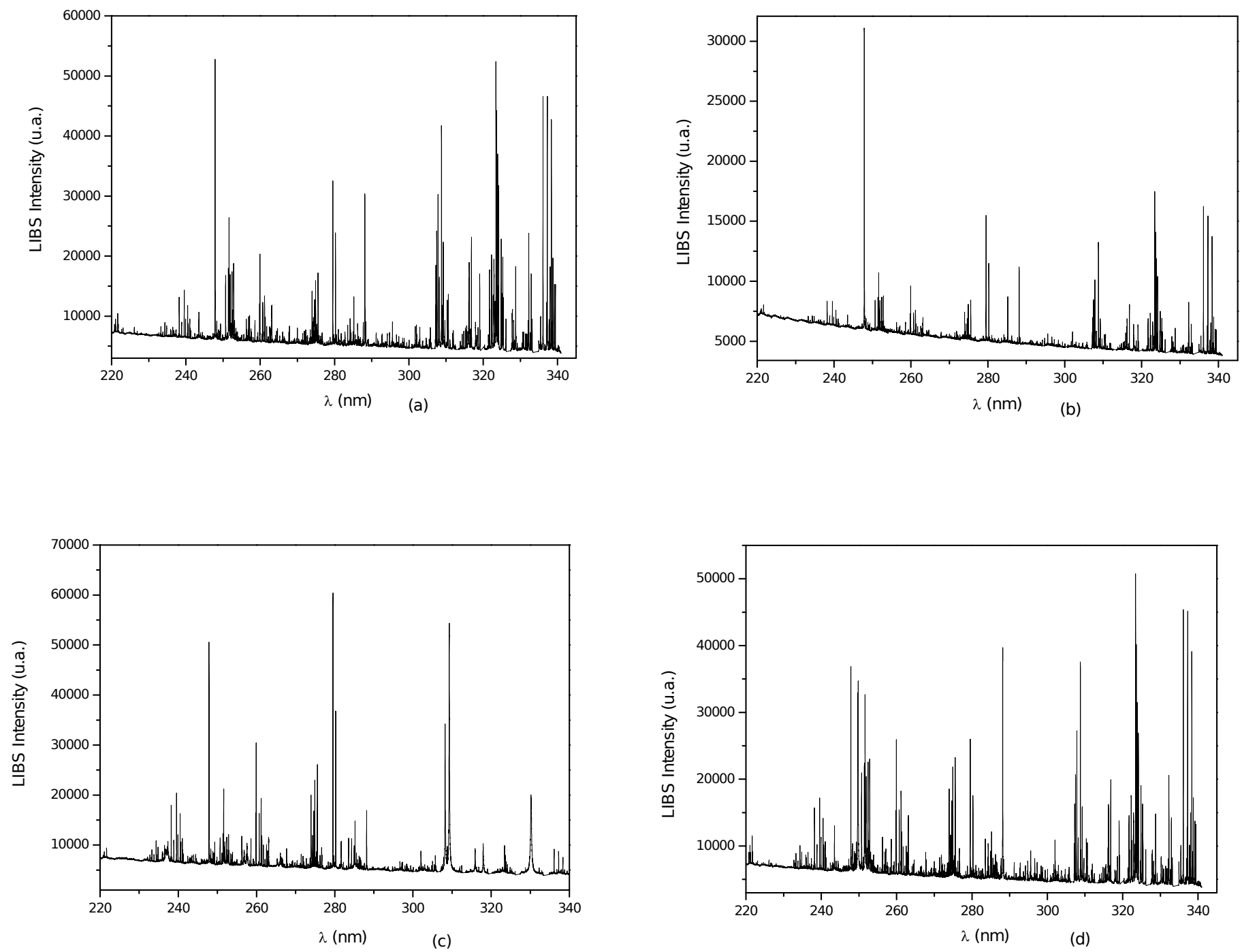
After obtaining the LIBS spectra, the data for specific lines were treated in order to determine the concentrations of $\mathrm{Fe}$ and $\mathrm{Al}$ present in the whole soil and in the humic fractions. The lines selected were as follows: $248.32708 \mathrm{~nm}(\mathrm{Fe} \mathrm{I}), 273.95474$ nm (Fe II), $302.04907 \mathrm{~nm}$ (Fe II), $265.2484 \mathrm{~nm}$ (Al I), $281.6185 \mathrm{~nm}$ (Al II), and 237.2070 nm (Al I). Three transitions were used for each metal, together with the background. A simple multivariate background analysis was used to obtain the LIBS intensity and correlate it with the concentration of $\mathrm{Fe}$ or $\mathrm{Al}$.

Figure 2 shows the graphs for the correlations between the LIBS intensities and the Fe concentrations $(\mathrm{g} / \mathrm{kg}$ ) obtained by FAAS analysis of the whole soil samples and the humic fractions. Very strong Pearson correlations were obtained for the humic acid and humin fractions, with $\mathrm{R}$ values of 0.95 and 0.97 , respectively (Figures 2(a) and 2(b)), while weaker correlations were found for the whole soils and the fulvic acid fractions. This suggested that the former two fractions, especially the humic acids, strongly participated in the transport of $\mathrm{Fe}$ to other horizons of the Amazonian Spodosols.

Figure 2. Correlations between the LIBS intensities and the Fe concentrations $(\mathrm{g} / \mathrm{kg})$ in the Amazonian Spodosol samples: (a) humic acids; (b) humin.

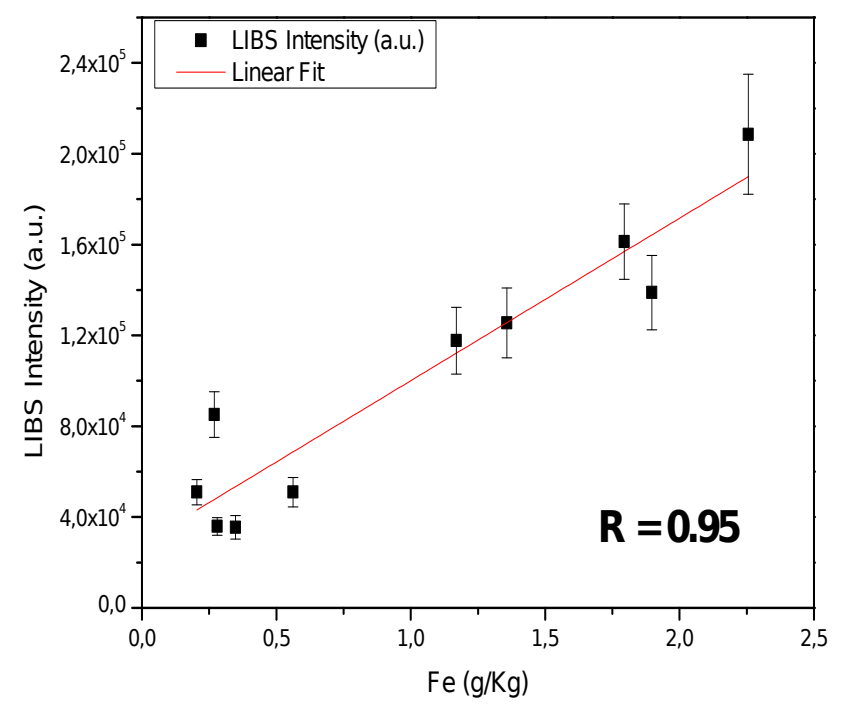

(a)

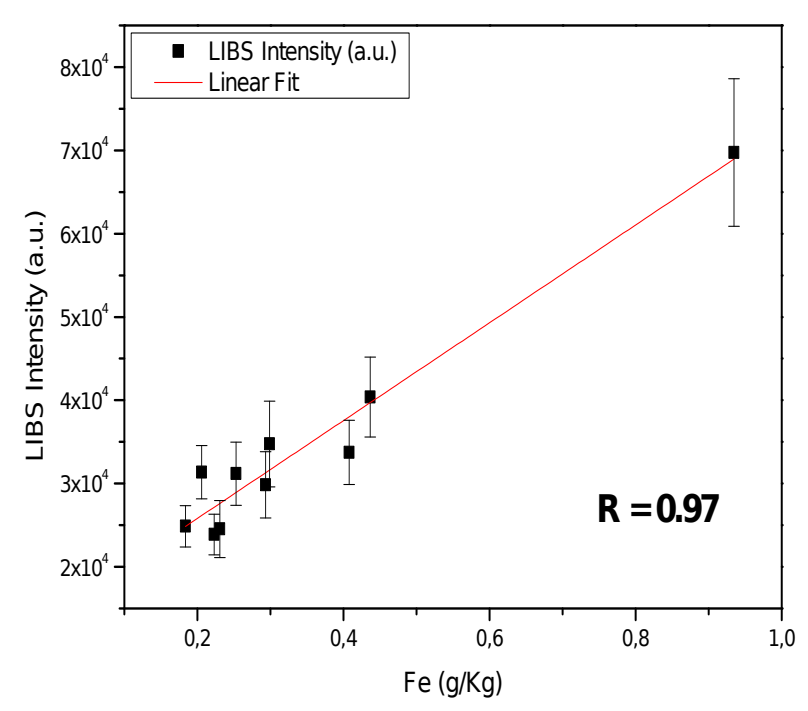

(b)

Figure 3 shows the correlation graphs for the LIBS intensity and [Al] $(\mathrm{g} / \mathrm{kg})$ determined by FAAS, for the whole soil samples and the fulvic acid fractions. Strong 


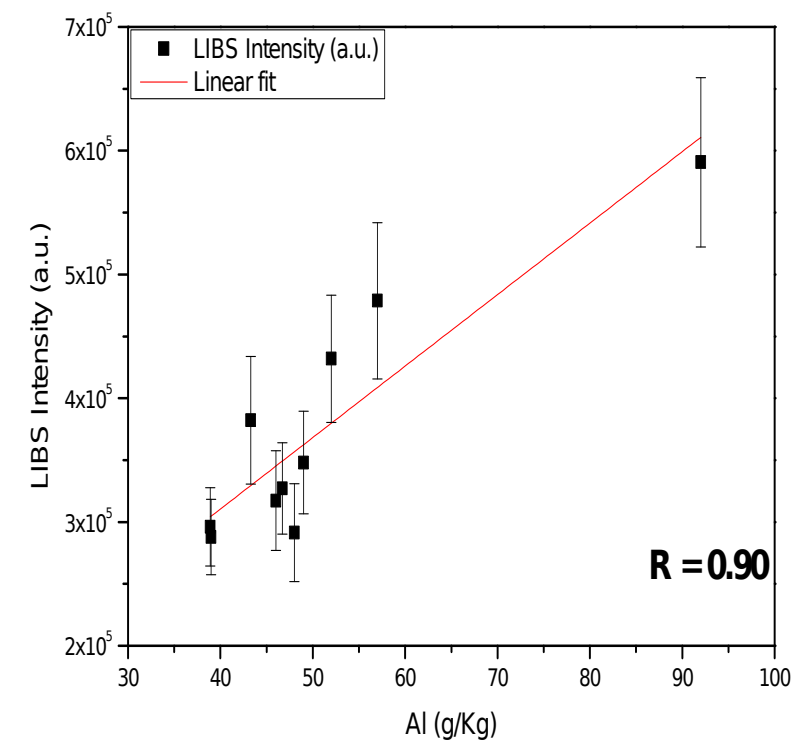

(a)

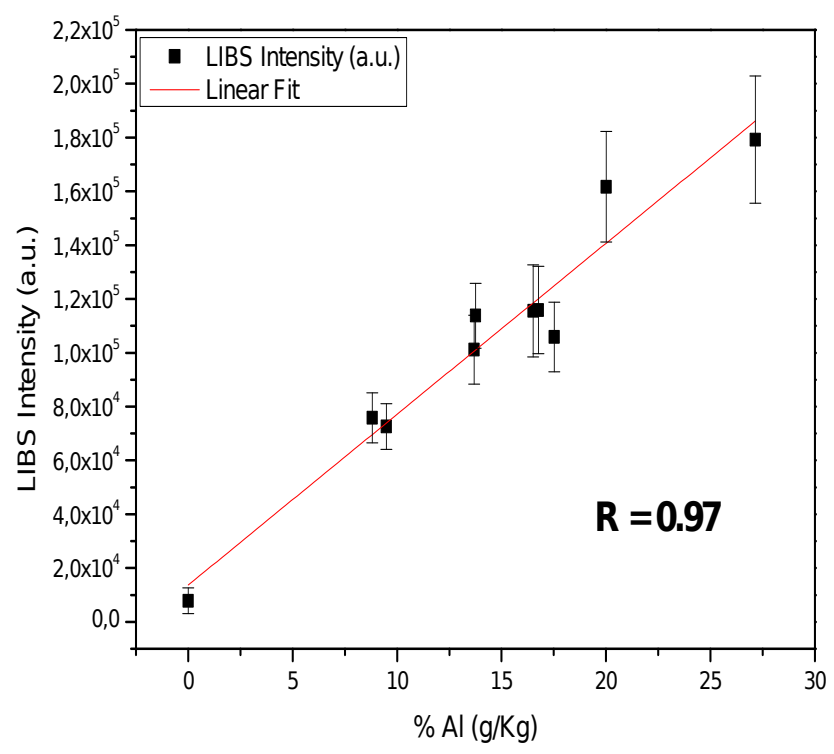

(b)

The results demonstrated that use of the LIBS technique enabled acquisition of important information concerning the humic fractions of the soil organic matter. In particular, it was possible to quantify the contributions of the different humic fractions to the processes of podzolization in these soils. The LIBS technique is faster than conventional techniques and was able to provide important information about key elements present in the humic fractions of organic matter in Amazonian soils.

\section{Conclusions}

The results showed that the fulvic acid fraction was associated with high 
amounts of $\mathrm{Al}$, while the humic acid fraction was more selective towards $\mathrm{Fe}$. The transfer of $\mathrm{Fe}$ and $\mathrm{Al}$ to deeper profiles involved young and less humified organic matter (soil P1), or older organic matter with a low degree of humification (soil P4). It could therefore be concluded that the three humic fractions (HA, FA, and HU) were involved in the soil podzolization process, with the FA and HA fractions playing predominant roles in the transport of $\mathrm{Al}$ and $\mathrm{Fe}$, respectively.

The potential of LIBS as a technique capable of assisting in investigation of the processes of formation of Amazonian Spodosols was also evaluated. The data obtained showed strong correlations with the results of analyses using the reference method (FAAS), for $\mathrm{Fe}$ in the humic acid and humin fractions $(\mathrm{R}=0.95$ and 0.97 , respectively), and for $\mathrm{Al}$ in the fulvic acid fraction $(\mathrm{R}=0.97)$. This is the first study using LIBS applied to samples of environmental humic fractions. In combination with FAAS, it enabled understanding of the roles of the humic fractions in the transport of nutrients and in the process of formation of Amazonian Spodosols.

\section{Acknowledgments}

The authors are grateful for the financial support provided by the São Paulo State Research Foundation (FAPESP, grants 2011/03250-2, 2012/51469-6, 2013/072761, and 2013/13013-3) and the Brazilian National Council for Technological and Scientific Development (CNPq, grants 303478/2011-0, 306674/2014-9, 150087/2017-9 and 232225/2014-1-SWE). The authors would like to thank Dr. Célia Regina Montes (ESALQ/ USP - Piracicaba, SP) for having given samples for analysis.

\section{References}

[1] S. Trumbore, P.B. Camargo. Dinâmica do carbono do solo, in: M. Keller, M. Bustamante, J. Gash, P. S. Dias (Eds.), Amazonia and Global Change, 2009, pp. 451462.

[2] D.S. Fanning, M.C.B. Fanning. Soil: morphology, genesis and classification. New York: John Willey \& Sons, 1989.

[3] C. Doupoux, P. Merdy, C.R. Montes, N. Nunan, A.J. Melfi, O.J.R. Pereira, Y. Lucas. Modelling the genesis of equatorial podzols: age and implications for carbon fluxes. Biogeosciences. 14 (2017) 2429-2440.

[4] F.J Stevenson. Humus chemistry: genesis, composition and reaction. 2. ed. New York: John Wiley, 1994. 
[5] A.G. Corrêa, V.G. Zuin. Química Verde: fundamentos e aplicações. Primeira ed.[s.1.] Edufscar, 2009.

[6] D.W. Hahn, N. Omenetto. Laser-Induced Breakdown Spectroscopy (LIBS), part I: review of basic diagnostics and plasma-particle interactions: still-challenging issues within the analytical plasma community. Appl. Spectrosc. 64 (2010) 335-366.

[7] E.C. Ferreira, D.M.B.P. Milori, E.J. Ferreira, L.M. Dos Santos, L. Martin-Neto, A.R.D.A. Nogueira. Evaluation of laser induced breakdown spectroscopy for multielemental determination in soils under sewage sludge application. Talanta 85 (2011) 435-440.

[8] G. Nicolodelli, B.S. Marangoni, J.S. Cabral, P.R. Villas-Boas, G.S. Senesi, C.H. Santos, R.A. Romano, A. Segnini, Y. Lucas, C.R. Montes, D.M.B.P. Milori. Quantification of total carbon in soil using laser- induced breakdown spectroscopy: amethod to correct interference lines. Appl. Opt. 53 (2104) 2170-2176.

[9] G. Nicolodelli, G.S. Senesi, R.A. Romano, I.L.O. Perazzoli, D.M.B.P. Milori. Signal enhancement in collinear double-pulse laser-induced breakdown spectroscopy applied to different soils. Spectrochim. Acta, Part B. 111 (2015) 23-29.

[10] P.R. Villas-Boas, R.A. Romano, M.A.M. Franco, E.C. Ferreira, E.J. Ferreira, S. Crestana, D.M.B.P. Milori. Laser-induced breakdown spectroscopy to determine soil texture: A fast analytical technique. Geoderma 263 (2016) 195-202.

[11] B.S. Marangoni, K.S.G. Silva, G. Nicolodelli, G.S. Senesi, J.S. Cabral, P.R. VillasBoas, C.S.S. Texeira, A.R.A. Nogueira, V.M. Benites, D.M.B.P. Milori. Phosphorus quantification in fertilizers using laser induced breakdown spectroscopy (LIBS): a methodology of analysis to correct physical matrix effects. Anal. Methods 8 (2016) 7882 .

[12] G. Nicolodelli, G.S. Senesi, I.L.O. Perazzoli, B.S. Marangoni, V.M. Benites, D.M.B.P. Milori. Double pulse laser induced breakdown spectroscopy: A potential tool for the analysis of contaminants and macro/micronutrients in organic mineral fertilizers. Sci. Total Environ. 565 (2016) 1116-1123.

[13] A.M. Tadini, G. Nicolodelli, G.S. Senesi, D.A. Ishida, C.R. Montes, Y. Lucas, S. Mounier, F.E.G. Guimarães, D.M.B.P. Milori. Soil organic matter in podzol horizons of the Amazon region: Humification, recalcitrance, and dating. Sci. Total Environ. 613614 (2018) 160-167.

[14] R. Boulet, A. Chauvel, F.X. Humbel, Y. Lucas. Analyse structurale et cartographie en pédologie: I - Prise en compte de l'organisation bidimensionelle de la couverture pédologique: les études de toposéquences et leurs principaux apports à la connaissance dês sols. Séries Pédologie 19 (1982) 309-321.

[15] R.D. Santos, R.C. Lemos, H.G. Santos, J.C. Ker, L.H.C. Anjos, L.H.C. Manual de descrição e coleta de solo no campo. Viçosa: Sociedade Brasileira de Ciência do Solo, 2005 . 
[16] Empresa Brasileira de Pesquisa Agropecuária (EMBRAPA). Sistema brasileiro de classificação de solos. Brasília, 2006. 306 p.

[17] J. Rice, P. Maccarthy. Isolation of humin by liquid-liquid partitioning. Sci. Total Environ. 81-82 (1989) 61-69.

[18] R.S. Swift. Organic matter characterization. In: D.L. Sparks, A.L. Page, P.A. Helmke, R.H. Loeppert, P.N. Soltanpour, M.A. Tabatabai, C.T. Johnston, M.E. Summer (Eds), Methods of soil analysis: chemical methods. Madison: Soil Science Society of America, Cap. 35, 2009, pp. 1018-1020.

[19] Environmental Protection Agency (EPA), Method 3052: microwave assisted acid digestion of siliceous and organically based matrices. Washington, 1996. 20 p.

[20] N. Keshava. Distance metrics and band selection in hyperspectral processing with application to material identification and spectral libraries. IEEE Transactions on Geoscience and Remote Sensing 42 (2004) 1552-1565.

[21] NIST Atomic Spectra Database, http://www.nist.gov/pml/data/asd.cfm, accessed February 2018.

[22] C.H. Santos. Estudo da matéria orgânica e composição elementar de solos arenosos de regiões próximas a São Gabriel da Cachoeira no Amazonas. 2014. 155 f. Tese (Doutorado em Química Analítica) - Instituto de Química de São Carlos, Universidade de São Paulo, São Carlos, 2014.

[23] F.A.O. Camargo, G.A. Santos, E. Zonta. Electrochemical Changes in wetland soils. Ciência Rural 29 (1999) 171-180.

[24] R. Sousa, F.A.O. Camargo, L.C. Vahl. Solos alagados: reações de redox. In: E.J. Meurer (Ed.), Fundamentos de química do solo. Porto ALegre: Evangraf, 2010. pp. 171-195.

[25] D. Ishida. Caracterização e Gênese de Solos e de Depósito de Caulim Associado, São Gabriel da Cachoeira - AM. 2010. 192 f. Tese (Doutorado em Geoquímica de Processos) - Instituto de Geociências, Universidade de São Paulo, São Paulo, 2010. 
Figure 1. Typical LIBS spectra for the hydromorphic spodosol (P1 A 0-15 cm): (a) whole soil, (b) humic acids, (c) fulvic acids, and (d) humin.
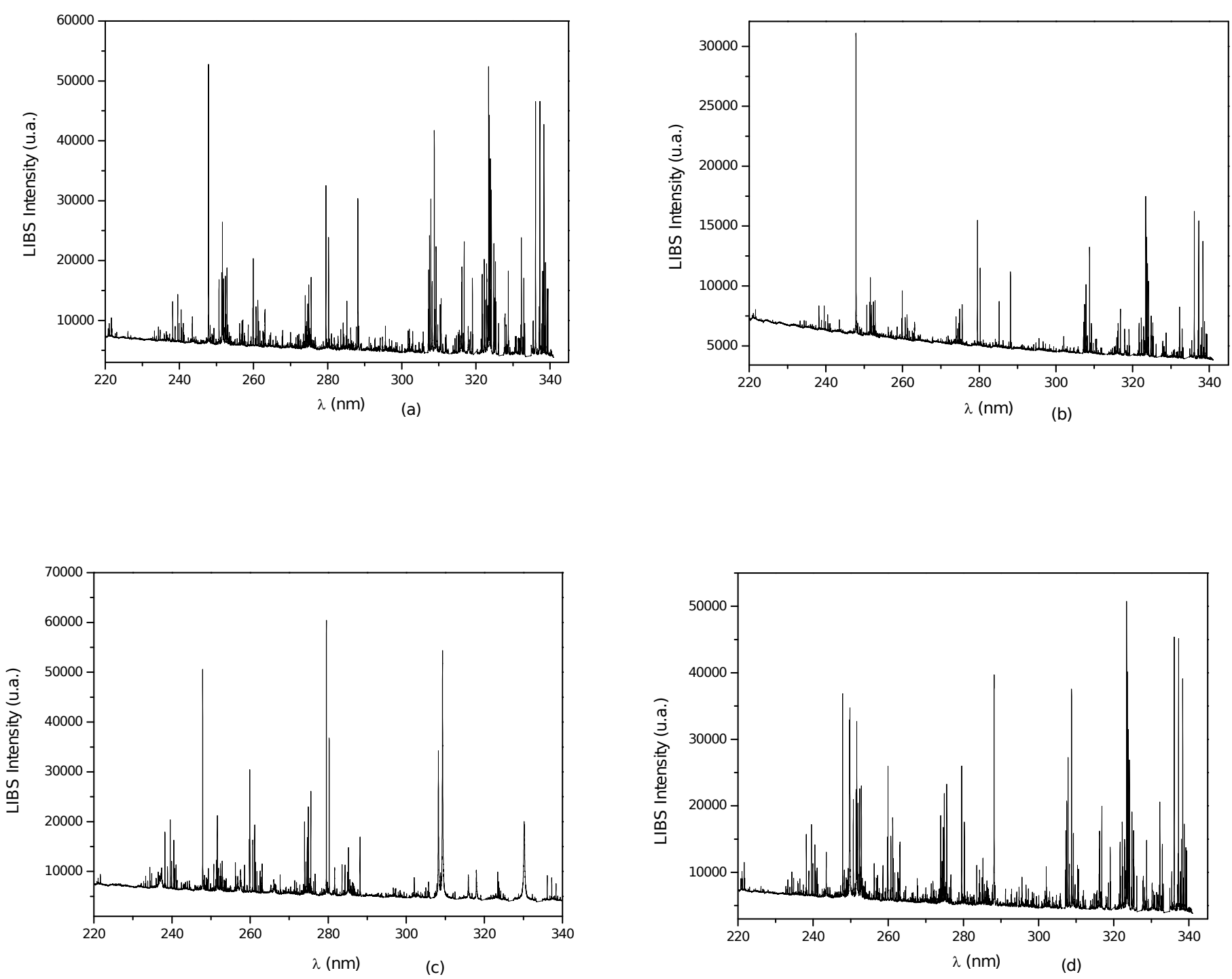
Figure 2. Correlations between the LIBS intensities and the Fe concentrations $(\mathrm{g} / \mathrm{kg})$ in the Amazonian Spodosol samples: (a) humic acids; (b) humin.

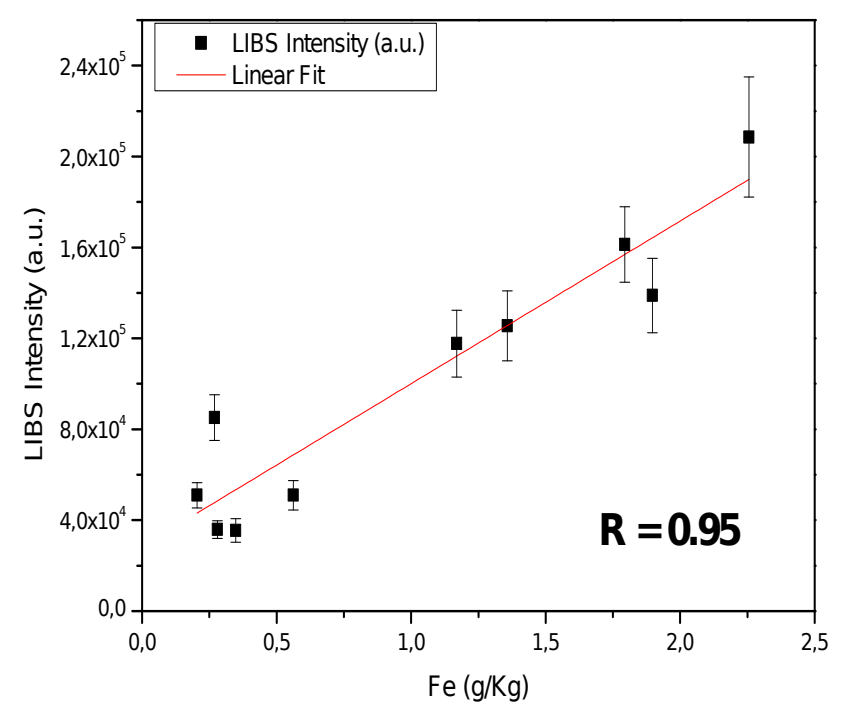

(a)

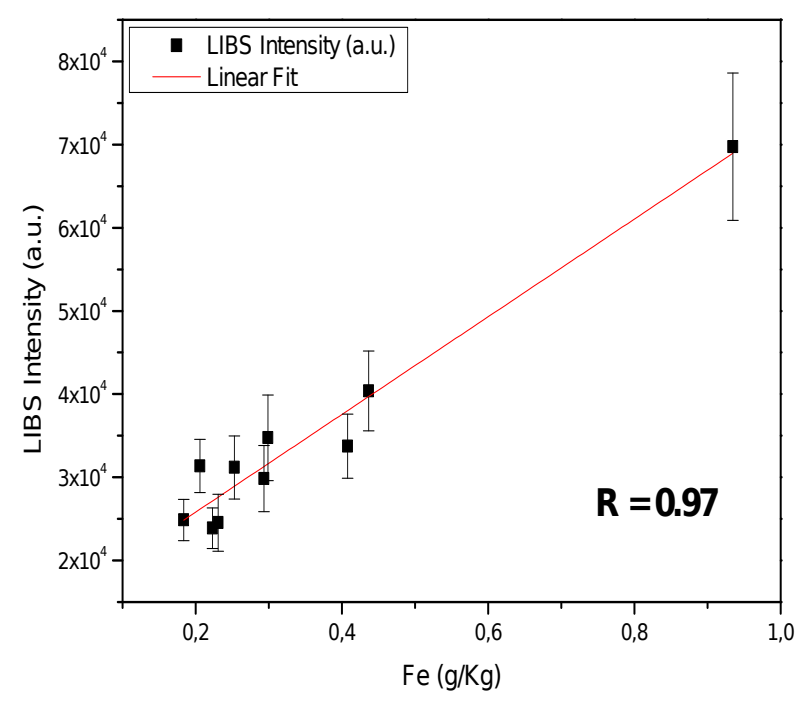

(b) 
Figure 3. Correlations between the LIBS intensities and the $\mathrm{Al}$ concentrations $(\mathrm{g} / \mathrm{kg})$ in the Amazonian Spodosol samples: (a) whole soil; (b) fulvic acids.

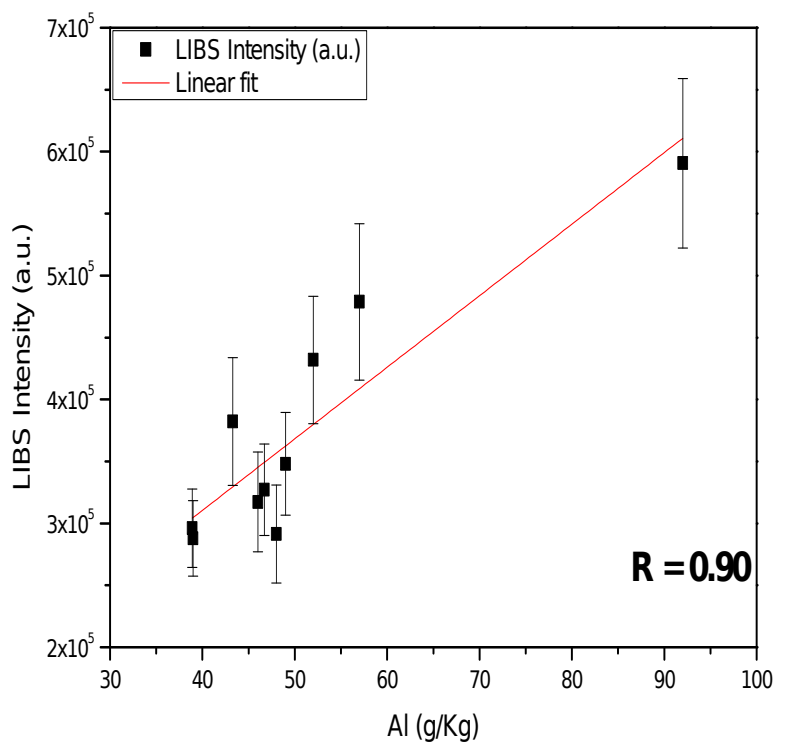

(a)

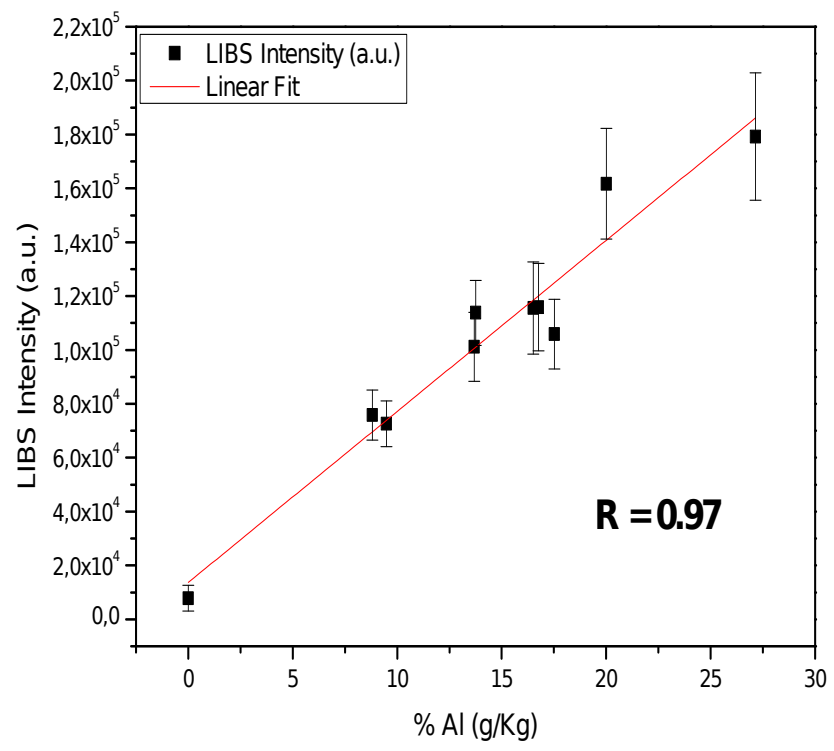

(b) 
Table 1. Concentrations of carbon (\%) and the metals $\mathrm{Fe}$ and $\mathrm{Al}(\mathrm{g} / \mathrm{kg})$ in the whole soil samples and in the humic fractions (HA, FA, and HU) extracted from the Amazonian

Spodosols.

\begin{tabular}{|c|c|c|c|c|c|c|c|c|c|c|c|}
\hline \multirow{2}{*}{ Metals } & \multicolumn{3}{|c|}{ Samples } & \multicolumn{4}{|c|}{ Carbon (\%) } & \multicolumn{4}{|c|}{ Concentration of metals $(\mathrm{g} / \mathrm{kg})$} \\
\hline & Area & Horizon & Depth (cm) & Soils & HA & FA & HU & Soils & HA & FA & HU \\
\hline \multirow{12}{*}{$\mathbf{F e}$} & \multirow{5}{*}{$\mathrm{P} 1$} & $\mathrm{~A}$ & $0-15$ & $22.5 \pm 0.9$ & $45 \pm 3$ & $18.2 \pm 0.5$ & $52.03 \pm 0.08$ & $1.20 \pm 0.01$ & $0.4 \pm 0.2$ & $0.07 \pm 0.01$ & $0.3 \pm 0.1$ \\
\hline & & A-E & $15-30$ & $1.01 \pm 0.09$ & $51 \pm 1$ & $26.9 \pm 0.2$ & $24.38 \pm 0.01$ & $0.95 \pm 0.01$ & $0.3 \pm 0.1$ & $*$ & $0.2 \pm 0.1$ \\
\hline & & $\mathrm{Bh}$ & $40-50$ & $2.1 \pm 0.2$ & $56.2 \pm 0.2$ & $36.8 \pm 0.8$ & $36.67 \pm 0.03$ & $0.77 \pm 0.01$ & $0.3 \pm 0.1$ & $0.12 \pm 0.01$ & $0.2 \pm 0.1$ \\
\hline & & $\mathrm{Bh}-\mathrm{C}$ & 240 & $3.2 \pm 0.2$ & $46 \pm 2$ & $47.9 \pm 0.1$ & $*$ & $6.44 \pm 0.01$ & $0.6 \pm 0.2$ & $*$ & $0.4 \pm 0.1$ \\
\hline & & $\mathrm{C}$ & 350 & $1.2 \pm 0.2$ & $51 \pm 3$ & $38.7 \pm 0.9$ & $5.17 \pm 0.00$ & $2.13 \pm 0.01$ & $0.2 \pm 0.1$ & $0.07 \pm 0.01$ & $1.0 \pm 0.2$ \\
\hline & \multirow{7}{*}{$\mathrm{P} 4$} & $\mathrm{~A}$ & $0-20$ & $3.9 \pm 0.2$ & $45.2 \pm 0.3$ & $34 \pm 3$ & $41.43 \pm 0.07$ & $2.29 \pm 0.01$ & $1.8 \pm 0.5$ & $0.2 \pm 0.1$ & $0.2 \pm 0.1$ \\
\hline & & A & $20-30$ & $3.5 \pm 0.2$ & $49.4 \pm 0.01$ & $21.6 \pm 0.2$ & $*$ & $2.28 \pm 0.01$ & $1.9 \pm 0.4$ & $*$ & $0.2 \pm 0.1$ \\
\hline & & A & $30-40$ & $0.89 \pm 0.01$ & $50 \pm 2$ & $10.8 \pm 0.1$ & $5.76 \pm 0.02$ & $2.60 \pm 0.01$ & $2.3 \pm 0.3$ & $*$ & $0.3 \pm 0.1$ \\
\hline & & $\mathrm{Bh}$ & $110-120$ & $0.42 \pm 0.02$ & $50.0 \pm 0.1$ & $39.8 \pm 0.6$ & * & $1.81 \pm 0.01$ & $1.1 \pm 0.2$ & $*$ & $0.4 \pm 0.1$ \\
\hline & & $\mathrm{Bh}$ & $170-180$ & $0.38 \pm 0.01$ & $52 \pm 6$ & $3.1 \pm 0.0$ & $5.33 \pm 0.02$ & $1.72 \pm 0.01$ & $1.4 \pm 0.2$ & $*$ & $0.3 \pm 0.1$ \\
\hline & & $\mathrm{Bh}$ & $370-380$ & $0.48 \pm 0.01$ & $52.8 \pm 0.3$ & $32.8 \pm 0.2$ & $2.26 \pm 0.01$ & $2.49 \pm 0.01$ & $1.2 \pm 0.6$ & $*$ & $0.4 \pm 0.1$ \\
\hline & & $\mathrm{Bh}$ & $380-390$ & $0.78 \pm 0.01$ & $54.5 \pm 0.5$ & $34.5 \pm 0.3$ & $*$ & $1.66 \pm 0.01$ & $1.3 \pm 0.2$ & $*$ & $0.3 \pm 0.1$ \\
\hline \multirow{12}{*}{ Al } & \multirow{5}{*}{$\mathrm{P} 1$} & $\mathrm{~A}$ & $0-15$ & $22.5 \pm 0.9$ & $45 \pm 3$ & $18.2 \pm 0.5$ & $52.03 \pm 0.08$ & $43 \pm 1$ & $*$ & $16.8 \pm 0.2$ & $*$ \\
\hline & & A-E & $15-30$ & $1.01 \pm 0.09$ & $51 \pm 1$ & $26.9 \pm 0.2$ & $24.38 \pm 0.01$ & $39 \pm 1$ & $*$ & $13.8 \pm 0.5$ & $*$ \\
\hline & & $\mathrm{Bh}$ & $40-50$ & $2.1 \pm 0.2$ & $56.2 \pm 0.2$ & $36.8 \pm 0.8$ & $36.67 \pm 0.03$ & $57 \pm 1$ & $*$ & $8.8 \pm 0.3$ & $*$ \\
\hline & & $\mathrm{Bh}-\mathrm{C}$ & 240 & $3.2 \pm 0.2$ & $46 \pm 2$ & $47.9 \pm 0.1$ & $*$ & $92 \pm 1$ & * & * & $*$ \\
\hline & & $\mathrm{C}$ & 350 & $1.2 \pm 0.2$ & $51 \pm 3$ & $38.7 \pm 0.9$ & $5.17 \pm 0.00$ & $52 \pm 1$ & $*$ & $20.0 \pm 0.1$ & $5.0 \pm 0.1$ \\
\hline & \multirow{7}{*}{$\mathrm{P} 4$} & $\mathrm{~A}$ & $0-20$ & $3.9 \pm 0.2$ & $45.2 \pm 0.3$ & $34 \pm 3$ & $41.43 \pm 0.07$ & $48 \pm 1$ & $6.4 \pm 0.4$ & $9.5 \pm 0.1$ & $*$ \\
\hline & & A & $20-30$ & $3.5 \pm 0.2$ & $49.4 \pm 0.01$ & $21.6 \pm 0.2$ & $*$ & $47 \pm 1$ & $*$ & $27.2 \pm 0.2$ & $*$ \\
\hline & & A & $30-40$ & $0.89 \pm 0.01$ & $50 \pm 2$ & $10.8 \pm 0.1$ & $5.76 \pm 0.02$ & $46 \pm 1$ & $*$ & $17.5 \pm 0.1$ & $*$ \\
\hline & & $\mathrm{Bh}$ & $110-120$ & $0.42 \pm 0.02$ & $50.0 \pm 0.1$ & $39.8 \pm 0.6$ & $*$ & $39 \pm 1$ & $*$ & $13.7 \pm 0.4$ & $*$ \\
\hline & & $\mathrm{Bh}$ & $170-180$ & $0.38 \pm 0.01$ & $52 \pm 6$ & $3.1 \pm 0.0$ & $5.33 \pm 0.02$ & $49 \pm 1$ & $*$ & $16.5 \pm 0.3$ & $*$ \\
\hline & & $\mathrm{Bh}$ & $370-380$ & $0.48 \pm 0.01$ & $52.8 \pm 0.3$ & $32.8 \pm 0.2$ & $2.26 \pm 0.01$ & $41 \pm 1$ & $*$ & $20.5 \pm 0.2$ & $*$ \\
\hline & & $\mathrm{Bh}$ & $380-390$ & $0.78 \pm 0.01$ & $54.5 \pm 0.5$ & $34.5 \pm 0.3$ & * & $51 \pm 1$ & * & $21 \pm 1$ & $*$ \\
\hline
\end{tabular}

P1: hydromorphic spodosol; P4: well drained spodosol; * below the detection limit of the calibration curve (\% $=0.04 ; \mathrm{Fe}: 0.10 \mathrm{mg} / \mathrm{kg}$ and Al: $2.5 \mathrm{mg} / \mathrm{kg})$. 